陳旧性アキレス腱断裂手術例の検討

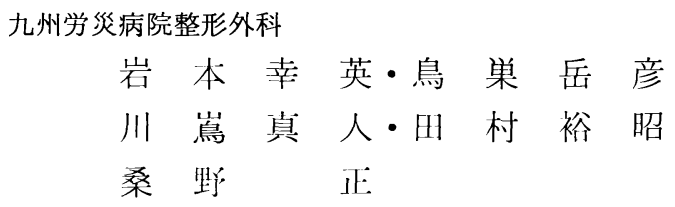

\title{
Results of Surgical Repair of Old Rupture of the Achillis Tendon
}

by

\section{Y. Iwamoto, T. Torisu, M. Kawashima,} H. Tamura and T. Kuwano

Orthopedic Surgery, Kyushu Rosai Hospital

\begin{abstract}
A follow up study and a clinical analysis of 11 patients of old achillis tendon rupture treated by surgical repair has been made.

Because of the inadequate diagnosis and treatment by the first doctor, all of these patients, except one, was led to be neglected.

The diagnosis of a partial rupture of the achillis tendon was made by the first doctor in 4 patients, but at the operation, all ruptures were found to be complete.

This should give cause to reconsider the easy diagnosis of the partial rupture of it.

More than a year after the operation, all of the patients, except one re-ruptured case, recoverd satisfactory and returned to heavy work and active sports.
\end{abstract}

\section{はじめに}

我々は，陳旧性アキレス腱断裂の手術例について， その術後成績を調査すると共に，診断および治療上の 問題につき，若干の検討を加えたので報告する.

\section{調 查 対 象}

症例は, 昭和 45 年から 54 年の 10 年間に, 当科に て手術を施行した陳旧性アキレス腱断裂 11 例である. 受傷後 4 週以上経過したものを陳旧例とした. その内 訳は, 男 4 例, 女 7 例, 皮下断裂 10 例, 開放断裂 1 例であった．年令は, 22 才より 71 才, 平均 46 才, 受 傷より手術までの期間は, 4 週より 1 年 10 ヶ月，平 均 4 ケ月である. 術後観察期間は, 4 ケ月より 10 年, 平均 3 年 8 ケ月である.

\section{受 傷 原 因}

スポーッによるもの6 例, 敷石のふみ外しによるも
の 2 例，登山によるもの 2 例，打撲によるもの 1 例で ある.

\section{初期診断および治療}

11 例中 10 例は, 受傷後遅く之も 2 週以内に, 他の 整形外科, 外科, 整骨院などを受診している. そのう ち, 完全断裂之診断されたもの 2 例, 部分断裂 4 例, 断裂なしの診断 4 例であった. 完全断裂の診断をうけ た 2 例中 1 例は, 他院で手術を受けたが, 術後早期に 再断裂をきたし， 1 年 10 ケ月後の当院での手術 所見 では約 $5 \mathrm{~cm}$ の断端開離を確認した. 残りの 1 例は, 手術をすすめられたが自ら物療院に転院し電気治療を 受けていた. 部分断裂, 断裂なしの診断例 8 例は, 実 際の手術所見では全て完全断裂であった．乙のよう に，今回の調查例では，陳旧例となった原因は，ほ之 んどが初期診断および治療の誤りにある. 


\section{陳|日例の症状}

脱力感，跛行，つま先立ち不可，階段を横向きに昇 降する，下駄で歩けないなどが主な症状で，疼痛はあ っても軽度である.

\section{診断}

病歴, 跛行の有無, Gap の確認, Thompson's squeeze test,つま先立ちの能力などにより総合的に判定 する.

\section{手術法}

陳旧例に対しては, 神中の半健様筋移植法, Bosworth の腓腹筋腱利用による有茎腱膜成形法， Zadek の大腿筋膜移植法, White-Kraynick の短腓骨 筋腱移行術, 伊藤らの足底竻腱移植法など, 種々の術 式が考案されている，我々は，まず内側縦切開を加え Bunnel 法による端々縫合を試みたが，受傷後 4 週の あの 3 例， 8 週のあの 1 例，計 4 例にて可能であっ た。腱断端の退縮が強く端々に縫合不能なもの 5 例に 対しては，皮切を上方に伸ばし，Bunnel 法にて断端 を引き寄せた上で，Bosworth 法に準じ腱条を翻転 して利用した。 また，翻転腱条が短く咪端間を十分に 縫縮できなかった 2 例に対しては，足底筋腱による補 強を追加した（図 1 ）。術後の固定は，原則として大 腿以下のギプス固定を，膝屈曲軽度尖足位にて 6 週間 施行している.

\section{術 後 成 績}

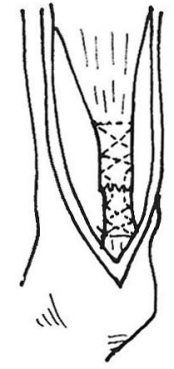

端々縫含

症

39 才，女性。バスケットボールにて受傷した，2 週 後，近医を受部するも，部分呠裂の䛦断をうけ湿布治 療をしていた，受傷後 4 ケ月にて当科初辦，完全坼裂 の診断のもとに手術を施行したが，手術時，瘷痕を除 去すると Gap が大きく, Bunnel 法で断端を引き寄 せ腱条を翻転固定し，更に足底筋腱にて補強した。術 後, 膌 $45^{\circ}$ 屈曲, 軽度尖足位で 6 週間ギプス固定. 術 後 1 年の現在，背屈制限はない。患例つま先立ち可能 で，マラソンも不自由なくできるようになった（図 $2)$.

術後，表在感染，皮膚壊死をきた したものが 1 例，再率裂をきたした あのが 1 例あった．全例つま先立ち は可能となった，底屈力について は，簡便法として，片脚つま先立ち の際の床腫間距離を用いたが, 11 例 中 9 例に, $1 \mathrm{~cm}$ 加ら $1.8 \mathrm{~cm}$ の健側 との差が見られ，多少の筋力の低下 は遺残する. 可動域制限について は，術後 4 ケ月しか経過していない 3 例は健側との比較で背屈制限があ るが， 1 年以上の経過例では全く差 がなかった、また， 1 年以上の経過 例中，再断裂例以外は全て日常生活

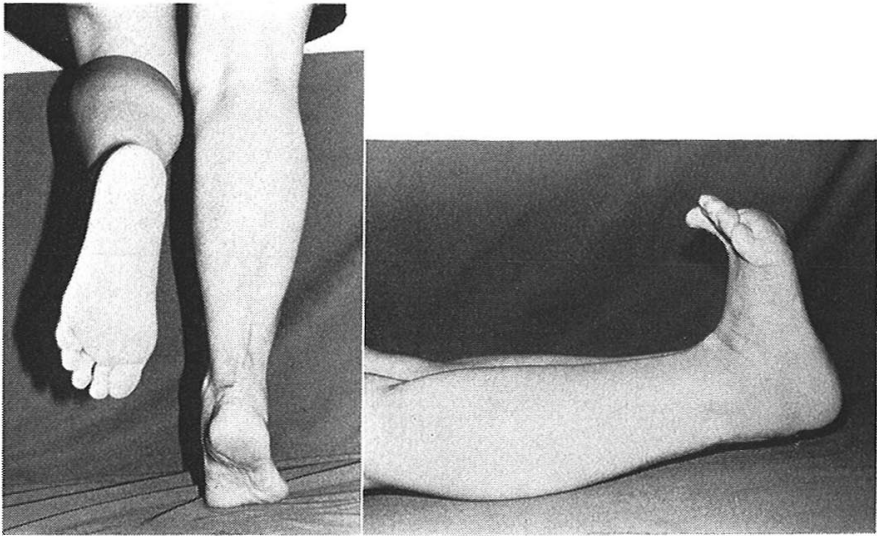

図2 術 後 1 年 
表 1 症例 の ま と め

\begin{tabular}{|c|c|c|c|c|c|c|c|c|c|c|c|c|c|c|}
\hline No. & 性 & 左右 & 程度 & $\begin{array}{l}\text { 開放 } \\
\text { 皮下 }\end{array}$ & $\begin{array}{l}\text { 手術 } \\
\text { まで }\end{array}$ & 原 因 & 前 医 & 診断 & 治療 & 手 術 法 & $\begin{array}{l}\text { 手 術 } \\
\text { 合併症 }\end{array}$ & $\begin{array}{ll}\text { 背 } & \text { 屈 } \\
\text { 制 } & \text { 限 }\end{array}$ & $\left|\begin{array}{l}\text { 床踵 } \\
\text { 距離 }\end{array}\right|$ & $\begin{array}{c}\mathrm{ADL} \\
\text { 制 限 }\end{array}$ \\
\hline 1 & 우 & 右 & 完全 & 皮下 & $4 \mathrm{~W}$ & $\begin{array}{l}\text { バレーボ } \\
\text { ール }\end{array}$ & 整 形 & $\left|\begin{array}{l}\text { 完全 } \\
\text { 断製 }\end{array}\right|$ & $\mid$\begin{tabular}{|} 
電気 \\
治療
\end{tabular} & Bunnel 法 & - & $\begin{array}{l}5^{\circ} \\
\left(15^{\circ}>\right. \\
\left.10^{\circ}\right)\end{array}$ & $1 \mathrm{c} \mathrm{m}$ & $\begin{array}{l}\text { 走 れ } \\
\text { な }\end{array}$ \\
\hline 2 & 우 & 右 & 完全 & 皮下 & $6 \mathrm{~W}$ & $\begin{array}{l}\text { バドミン } \\
\text { トン }\end{array}$ & $\begin{array}{l}\text { 整骨院 } \\
\text { 整 形 }\end{array}$ & 断裂 & 湿布 & \begin{tabular}{|l} 
Bunnel 法 \\
Bosworth 法 \\
Plantaris 利用
\end{tabular} & $\begin{array}{l}\text { 表在感 } \\
\text { 染皮廙 } \\
\text { 壊死 }\end{array}$ & $\begin{array}{l}15^{\circ} \\
\left(15^{\circ}>\right. \\
\left.0^{\circ}\right)\end{array}$ & 1.3 & $\begin{array}{ll}\text { 走 } & \text { な } \\
\text { な }\end{array}$ \\
\hline 3 & 우 & 右 & 完全 & 皮下 & $8 \mathrm{M}$ & $\begin{array}{l}\text { 敷石ふみ } \\
\text { 外し }\end{array}$ & 外 科 & $\mid$ & 湿布 & $\begin{array}{l}\text { Bunnel 法 } \\
\text { Bosworth 法 }\end{array}$ & - & $\begin{array}{l}10^{\circ} \\
\left(15^{\circ}>\right. \\
\left.5^{\circ}\right)\end{array}$ & 0 & 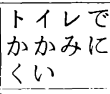 \\
\hline 4 & $\hat{\delta}$ & 右 & 部分 & 皮下 & $4 \mathrm{~W}$ & $\begin{array}{l}\text { ソフトボ } \\
\text { ール }\end{array}$ & 外 科 & $\left|\begin{array}{l}\text { 部分 } \\
\text { 断裂 }\end{array}\right|$ & 湿布 & Bunnel 法 & - & 0 & 1 & - \\
\hline 5 & 우 & 右 & 完全 & 皮下 & $8 \mathrm{~W}$ & 登山 & I & / & l & Bunnel 法 & - & 0 & 0 & - \\
\hline 6 & $\hat{o}$ & 右 & 完全 & 皮下 & $\begin{array}{l}1 \mathrm{Y} \\
10 \mathrm{M}\end{array}$ & 登 山 & $\begin{array}{l}\text { 整 形 } \\
\text { 外科 }\end{array}$ & $\left|\begin{array}{c}\text { 完全 } \\
\text { 断裂 }\end{array}\right|$ & 手術 & $\begin{array}{l}\text { Bunnel 法 } \\
\text { Bosworth 法 }\end{array}$ & - & 0 & 1.2 & - \\
\hline 7 & ㅇ & 右 & 完全 & 皮下 & $4 \mathrm{M}$ & $\begin{array}{l}\text { バスケッ } \\
\text { ドール }\end{array}$ & 外 科 & 部分 & 湿布 & $\begin{array}{l}\text { Bunnel 法 } \\
\text { Bosworth 法 } \\
\text { Plantaris 利用 }\end{array}$ & - & 0 & 1.0 & - \\
\hline 8 & 全 & 右 & 完全 & 皮下 & $7 \mathrm{~W}$ & $\begin{array}{l}\text { ラン } \\
\text { グ }\end{array}$ & 外科 & $\left|\begin{array}{c}\text { 断裂 } \\
ナ \\
ナ シ \mid\end{array}\right|$ & 湿布 & $\begin{array}{l}\text { Bunnel 法 } \\
\text { Bosworth 法 }\end{array}$ & - & 0 & 1.0 & - \\
\hline 9 & $\hat{\delta}$ & 右 & 完全 & 皮下 & $3 \mathrm{M}$ & $\begin{array}{l}\text { ラン ニン } \\
\text { グ }\end{array}$ & 外 科 & \begin{tabular}{|l|} 
部分 \\
断裂
\end{tabular} & 湿 布 & $\begin{array}{l}\text { Bunnel 法 } \\
\text { Bosworth 法 }\end{array}$ & - & 0 & 1.3 & - \\
\hline 10 & 우 & 右 & 完全 & 皮下 & $4 \mathrm{~W}$ & $\begin{array}{l}\text { 敷石ふみ } \\
\text { 外し }\end{array}$ & 外 科 & 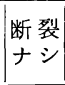 & 湿布 & Bunnel 法 & 再断裂 & 0 & 1.8 & $\mid \begin{array}{ll}\text { 走 } & れ \\
な & い\end{array}$ \\
\hline 11 & 우 & 右 & 完全 & 開放 & $\begin{array}{l}4 \mathrm{M} \\
2 \mathrm{~W}\end{array}$ & 打 & 整 形 & $\mid \begin{array}{l}\text { 断裂 } \\
ナ\end{array}$ & 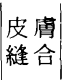 & $\begin{array}{l}\text { Bunnel 法 } \\
\text { Bosworth 法 }\end{array}$ & - & 0 & 1.0 & - \\
\hline
\end{tabular}

背屈制限および床踵間距離は，健側との差を示す.

考察

\section{部分断裂について}

今回の調査では，陳旧例となった原因は，ほとんど が初期猃断および治療の誤りによるあのであったが, そのうち 4 例が部分断裂の診断のもとに湿布治療を受 けていた．しかし，手術所見では全例完全断裂であっ た. 諸家の報告であ部分断裂の頻度は著しく低く, 診 断は困難で，一部ではその存在すら疑われている. Rolf Ljungqvist は, 部分断裂 24 例につき報告して いるが, その中で, 部分断裂の病歴, 理学所見に特徵 的なものはなく, 完全断裂, アキレス腱周囲炎, 足関 節捻挫, Bursitis などとの鑑別を要し，その診断には 病歷, 理学所見に加え, レ線, 筋電図学的検討を要す と述べており，部分断裂の診断確定には慎重を要す る.

治療法について
Lea, Gillies らは，ギプス固定によるアキレス腱断 裂の 保存治療の有用性を説き，その中で 新鮮例に加 え，ギプス固定にて治ゆした陳旧例を紹介している が，陳旧例ではいずれの手術所見でも断端間を痏痕組 織が埋めており，腱は延長した状態になっているの で，手術的に瘢痕を除去し腱を再建せ齐ば機能は回復 しないと考える．手術法としては，陳旧例においてあ 我々はまず端々梿合を目標とする，今回の調查では， 11 例中, 受傷後 4 週のもの 3 例, 8 週のもの 1 例の 計 4 例にて端々縫合可能であった. 腱退縮のため端々 縫合不能のものに対しては, 皮切を上方に延長すれば 容易に応用でき，手技が簡単なととから Bosworth 法を愛用している.しかし，中には，十分な長さの翻 転腱条を採取できず断端間を十分に縫縮できないもの ああり，乙のようなあのには足底筋腱を利用し補強す る. 以上の三術式を症例により使い分けたが，いずれ の方法であ結果は良好であった．また，術後のギプス 
固定は，非尖足位歩行を早めるため，尖足は軽度に之 どめることが肝要であり，その分膝を十分屈曲するこ とにより腓腹筋を減張させて代償する. そのため固定 肢位は，膝屈曲位，軽度尖足位を原則とする。 しか し，陳旧例では Gap が大きいため，断端を引き寄せ て絶縮すると尖足は高度となりがちである．乙のよう な症例であ，尖足の矯正に時間はかかるが， 1 年以上 経過すると背屈制限はなくなる．また，固定期間は，

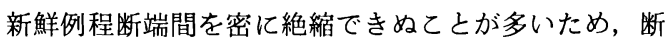
端間再連絡に，より時間を要すと考え，新鮮例 4 週に 比し，陳旧例 6 週と，長期間施行している.

\section{結語}

1. 当院における陳旧性アキレス腱断裂の手術例 11 例につき, 術後成績を調査し, 診断および治療上の問 題について検討を加えた.

2. 術後 1 年以上経過した症例では, 可動域制限は なく，日常生活動作，スポーツにあ支障はない．

3. 陳旧例となった原因は，ほとんどが初期診断お よび治療の誤りであったが，特に部分断裂の診断をう けた 4 例はすべて完全断裂であった. 部分断裂の診断 には慎重を要する。

\section{文献}

1) Bosworth, D. M.: Repair of defects in the tendo achillis. J. Bone \& Joint Surg., 38-A : 111-114, 1956.

2) Gillies, H.: The management of fresh ruptures of the tendo achillis. J. Bone \& Joint Surg., 52-A : 337-343, 1970.

3) Lea, R. B.: Non-Surgical treatment of tendo achillis rupture. J. Bone \& Joint Surg., 54-A : 1398-1407, 1972.

4) Ljungqvist, R.: Subcutaneous partial rupture of the achillis tendon. Acta Orthop. Scandinav. Suppl. 113: 1968.

\section{啠 問大 野村 茂治} 30 年前にアキレス腱断裂の患者を診療する機会を 得たが，走行不可なるも他に日常生活に困らないとい うことであった。

最長陳旧例の愁訴はいかなるものであったか.

\section{質問に対する回答}

1 年 10 ケ月経過例が最長であったが，脱力感，階 段を横向きにしか昇降できない，下駄をはいて歩きに くい，などの症状があった. 